Original Article

\title{
Photosynthetic metabolism and antioxidant in Ormosia arborea are modulated by abscisic acid under water deficit?
}

\author{
Metabolismo fotossintético e antioxidante em mudas de Ormosia arborea são \\ modulados pelo ácido abscísico sob deficit hídrico?
}

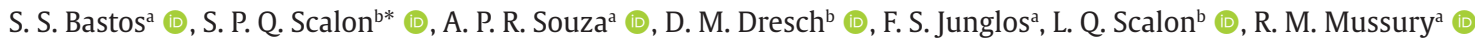 \\ and V. M. B. Freitas ${ }^{\mathrm{b}}$ (D) \\ a Universidade Federal da Grande Dourados - UFGD, Faculdade de Ciências Biológicas e Ambientais - FCBA, Dourados, MS, Brasil

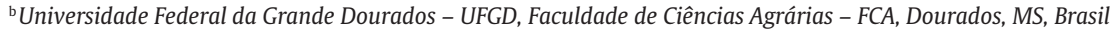

\begin{abstract}
The aim of this research was to evaluate the effect of abscisic acid (ABA) on gas exchange and the activity of antioxidant enzymes of Ormosia arborea (Vell.) Harms seedlings under water deficit and its influence on the recovery potential of the seedlings. The experiment was conducted using four treatments, being daily irrigation or water restriction without and with $10 \mu \mathrm{M}$ ABA. Seedlings under water deficit + ABA showed greater adjustment to drought, and when re-irrigated, they restored photosynthetic metabolism and water potential. ABA minimizes the reduction in the photosynthetic metabolism and water potential of the leaf, however, it does not increase the antioxidant activity of the 0 . arborea seedlings under water deficit. These results suggest that this species exhibits plasticity, which enables it to survive also in environments subjected to temporary water deficit regardless of the supplementation of ABA. We suggest that other doses of $A B A$ be researched to expand the beneficial effect of $A B A$ on this species.
\end{abstract}

Keywords: gas exchange, antioxidant enzymes, water stress, ABA.

\begin{abstract}
Resumo
O objetivo deste trabalho foi avaliar o efeito do ácido abscísico (ABA) nas trocas gasosas e na atividade de enzimas antioxidantes de mudas de Ormosia arborea (Vell.) Harms sob deficiência hídrica e sua influência no potencial de recuperação das mudas. $O$ experimento foi conduzido com quatro tratamentos, sendo eles irrigação diária ou restrição hídrica sem e com $10 \mu \mathrm{M}$ ABA. As mudas sob déficit hídrico + ABA apresentaram maior ajuste à seca e ao serem re-irrigadas restabeleceram o metabolismo fotossintético e o potencial hídrico. $O$ ABA minimizou a redução do metabolismo fotossintético e do potencial da água na folha, porém, não aumentou a atividade antioxidante de mudas de 0 . arborea sob déficit hídrico. Esses resultados sugerem que esta espécie apresenta plasticidade fisiológica, o que lhe permite sobreviver em ambientes sujeitos a déficit hídrico temporário, independente da suplementação de ABA. Sugerimos que outras doses de ABA sejam avaliadas para ampliar os efeitos benéficos do ABA sobre esta espécie.
\end{abstract}

Palavras-chave: trocas gasosas, enzimas antioxidantes, estresse hídrico, ABA.

\section{Introduction}

The impacts caused by climate change on biodiversity, according to a review of Rodrigues et al. (2015), is a theme that has already aroused the interest of researchers since the last decade, which emphasize the importance of considering their consequences on the distribution or mortality of tree species and desertification in some more arid areas.

Environmental factors, with water stress, influence the growth, development, and productivity of plants (Okasabe et al., 2014; Taiz et al., 2017; Junglos et al., 2018). Resende et al. (2019) highlighted that many studies report the biochemical responses of plants to water stress, however most species are of economic interest and few address endangered species. Water stress due to water

restriction results in a decreased transpiration rate and affect biochemical and physiological process. It also affects the metabolism of nutrients and plant growth regulators, photosynthesis, respiration, and translocation of photo-assimilates. Consequently, water stress reduces plant growth (Campelo et al, 2015; Moraes et al., 2015; Taiz et al., 2017; Junglos et al., 2018).

Plants may also have an endogenous increase in abscisic acid (ABA) concentration in a root that is translocated to the aerial part, where it can trigger stomatal closure in the leaves. This reduces water loss through transpiration and reduction in photosynthesis (Pantin et al., 2012; Taiz et al., 2017) 
Another response to conditions of water deficit is the production of reactive oxygen species (ROS), which can bind to vital molecules such as fats, proteins, and nucleic acids. This causes lipid peroxidation, protein denaturation, DNA mutation and RNA damage and these effects can lead to cell death. In this context, ABA and ROS are messenger molecules that induce antioxidant defense (Shinozaki and Yamaguchi-Shinozaki, 1997). To defend themselves, plants create antioxidant enzymatic systems to normalize free radicals; an example is superoxide dismutase (SOD), catalase (CAT) and in ascorbate peroxidase (APX) (Carneiro et al., 2011).

Ormosia arborea (Vell.) Harms is a tree species that can be found in the Atlantic Rainforest of Brazil, as well as in semideciduous broadleaf forests and the gallery forests of the Cerrado ecosystem (Lorenzi, 2008; Carvalho, 2004). The species is secondary to late climax, being recommended for plantations intended for recovery of degraded areas of permanent preservation and restoration of riparian environments in locations under conditions of water-logging or temporarily flooded (Carvalho, 2004; Junglos et al., 2018). It provides for these locations, high accumulation of biomass and nutrients and maintenance of water resources and soil. The wood is used in construction and carpentry, being employed in the manufacture of panels and sliced blades for internal finishes. The tree is also used as ornamental and can be used in planting on streets and avenues, as it offers good shade (Lorenzi, 2008; Carvalho, 2004).

Information about the development of this species is scarce, especially with water deficit, which would facilitate a better understanding of the interactions caused by water stress in physiological processes and in the development of the seedlings of that species. Thus, the analysis of the changes of physiological characteristics in response to the availability of resources and assessment of the plasticity can enable a better interpretation of the habitat preferences of these species (Goulart et al., 2011).

Considering the effect of abscisic acid (ABA) in stomatal closure and maintenance of turgescence of the cells under a hydric deficit, which contributes to antioxidant defense, we hypothesized that gas exchange and antioxidant activities in 0 . arborea seedlings could be modulated by $\mathrm{ABA}$, stimulating greater adjustment to water deficit and recovery after suspension of stress. Thus, the aim of this research was to evaluate the effect of $A B A$ in gas exchange and the activity of antioxidant enzymes of 0 . arborea seedlings under water restriction and its influence on the recovery potential of the seedlings.

\section{Material and Methods}

\subsection{Study area and treatments}

The study was carried out at the College of Agricultural Science at the Federal University of Grande Dourados (UFGD), in the municipality of Dourados, Mato Grosso do Sul/Brazil. Nineteen-month-old 0 . arborea seedlings were grown in pots with $8 \mathrm{~L}$ capacity, with one seedling per pot. The voucher specimen was deposited in the DDMS/UFGD herbarium (registration number 5206). The experiment was conducted in a greenhouse in a protected environment without temperature or humidity control. The average data temperature internal and external from inside the plastic cover were the $21.4^{\circ} \mathrm{C}$ and $27.2^{\circ} \mathrm{C}$, respectively. The internal and external relative humidity presented average the 54 and, $67 \%$, respectively. The plants were maintained under $30 \%$ shade and protected from precipitation by keeping them under a plastic covering during the experiment.

The experiment consisted of four treatments: 1) daily irrigation without $\mathrm{ABA}(\mathrm{I}) ; 2$ ) daily irrigation $+10 \mu \mathrm{M}$ $\mathrm{ABA}$ (I 10); 3) water restriction without ABA (SI); and 4) water restriction $+10 \mu \mathrm{M} \mathrm{ABA}$ (SI 10). The choice of a $10 \mu \mathrm{M}$ dose was due to previously conducted tests and based on Pacheco et al. (2011). Each treatment consisted of four replicates with two seedlings in each treatment.

The results were evaluated over five periods: T0 - time zero (beginning of the experiment); $1^{\text {st }} \mathrm{P0}$ - the first time photosynthesis was close to zero (at 29 days), $2^{\text {nd }} P 0$, the second time photosynthesis was close to zero (at 105 days); REC - recovery (at 127 days); and END-end evaluation (at 191 days).

For the irrigation treatments, the seedlings were divided into two groups:

- The first group was irrigated daily during the entire period of the experiment, and the soil was maintained at $70 \%$ of its water retention capacity (I) acording to (Souza et al., 2000);

- The second group(SI) was subjected to water restriction equivalent to $40 \%$ of the water retention capacity for 19 days. Then irrigation was entirely suspended until the photosynthetic rate approached zero ( $\left.1^{\text {st }} \mathrm{P0}\right)$. Starting at the $1^{\text {st}} \mathrm{P0}$, all pots were watered daily until the retention capacity of $70 \%$ of the substrate. That irrigation was maintained until it reached similar levels of photosynthesis from those that were irrigated (first group). After 26 days of photosynthetic activity similar between groups, another cycle of water suspension was conducted ( $69^{\text {th }}$ day), and the seedlings were evaluated until the photosynthetic rate approached zero $\left(2^{\text {nd }} \mathrm{PO}-\right.$ $105^{\text {th }}$ day). At that point, the seedlings were re-irrigated until they reached similar levels of photosynthesis as those that were irrigated (first group) (REC - 127 day), with assessments until the 191 days (END).

Two applications of ABA were performed. The first application occurred at time zero (T0, beginning of the experiment), and the second application occurred 25 days after the second suspension of irrigation ( $94^{\text {th }}$ day), based on the photosynthetic rate being close to one.

\subsection{Evaluations}

The control seedlings (I) were evaluated in the same periods as the seedlings with water restriction (SI). Gas exchange was determined every 2 days and out her characteristics (water potential, potential quantum efficiency of photosystem II and antioxidant enzymes activity) assessed at the times labeled T0, $1^{\text {st }}$ and $2^{\text {nd }} \mathrm{PO}$, REC, and END. The seedlings were monitored for survival in relation to the number initially used in the T0. 


\subsection{Gas exchange analysis}

Gas exchange assessments were performed with a LCl Pro-SD ADC BioScientific Ltd. portable photosynthesis meter. Measurements were taken to assess: $A$ - photosynthetic rate $\left(\mu \mathrm{molm}^{-2} \mathrm{~s}^{-1}\right)$; gs - stomatal conductance $\left(\mathrm{mol} \mathrm{m}^{-2} \mathrm{~s}^{-1}\right)$; E - transpiration $\left(\mathrm{mmolm}^{-2} \mathrm{~s}^{-1}\right)$, and $\mathrm{Ci}$ - intercellular concentration of $\mathrm{CO}_{2}\left(\mu \mathrm{molmol}^{-1}\right)$, as well as $\mathrm{A} / \mathrm{Ci}$ carboxylation efficiency $\left(\mu \mathrm{mol} \mathrm{m} \mathrm{m}^{-2} \mathrm{~s}^{-1} / \mu \mathrm{mol}^{-1} \mathrm{H}_{2} \mathrm{O}\right)$ and

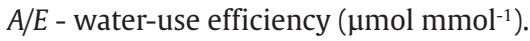

\subsection{Leaf water potential}

The leaf water potential ( $\Psi w$ ) was obtained from readings held in individual sheets belonging to the second pair of fully expanded leaves from the apex to the base, between 10:00 and 11:00 AM, using a pressure (Portable Plant Water Status Console-3115 model).

\subsection{Chlorophyll a fluorescence analysis}

The potential quantum efficiency of photosystem II (Fv/Fm) was assessed using an OS-30P portable fluorometer (Opti-Sciences Chlorophyll Fluorometer, Hudson, USA). The leaves were subjected a during 30-min of adaptation to the dark with the aid of adaptive clips, so that all reaction centers in the leaf region acquired the condition of "open", i.e., there was complete oxidation of the photosynthetic electron transport system. Fluorescence and gas exchange were determined between 8:00 and 11:00 AM on the same leaves used for gas exchange assessments.

\subsection{Antioxidant enzymes activity}

The 0 . arborea leaves and roots subjected to the treatments were harvested, and the material was frozen in liquid nitrogen. From each sample,1g was weighed to be macerated in $6 \mathrm{ml}$ from the solution containing $0.3 \mathrm{~g}$ of polyvinylpyrrolidone (PVP) diluted in $100 \mathrm{ml}$ of potassium phosphate buffer $(0.2 \mathrm{M})$. Then the samples were centrifuged at $4000 \mathrm{rpm}$ for $20 \mathrm{~min}$ at $4{ }^{\circ} \mathrm{C}$, and the supernatant was used as an enzyme extract. Quantification of the activity of the enzymes catalase (CAT), peroxidase (POD), and superoxide dismutase (SOD) was conducted according to methodology of Broetto (2014).

\subsection{Experimental design and statistical analysis}

For the gas exchange data, the design was completely randomized with four treatments with four repetitions, with each repetition corresponding to one seedling. The results were subjected to analysis of variance (ANOVA). After significance was determined, the means were submitted to the Scott-Knott test at 5\% probability.

For the fluorescence data regarding chlorophyll $a$, water potential, and the activity of antioxidant enzymes, the design was completely randomized in a split plot design where the main plot corresponded with the treatments, and the subplots were the assessment periods. The results were subjected to ANOVA and, after significance was determined, the means of the treatments and their interaction with assessment times were subjected to Tukey's test at 5\% probability. This was done using the SISVAR statistical program (Ferreira, 2011).

\section{Results}

The analysis of variance showed that for the data of gas exchange there was a significant difference between the treatments on each day of evaluation. For the data like water potential, potential quantum efficiency of photosystem II and antioxidant enzymes activity we observed significant interaction between the factors (treatments $\mathrm{x}$ evolutions periods).

The seedlings showed 100\% survival over the evaluations. In the first cycle of null photosynthesis $(A)\left(1^{\text {st }} \mathrm{P} 0\right)$, the seedlings of the treatments under water deficit exhibited the sharpest reduction in photosynthetic rate on the $27^{\text {th }}$ day (Figure 1a). However, the treatment without any dose of ABA showed a lower tolerance to drought compared to the treatment receiving $A B A$. The photosynthetic rates of these treatments showed a marked reduction. On the $29^{\text {th }}$ day, the treatment without ABA (SI) reached a photosynthetic rate close to zero. However, for the seedlings from the treatment with a $10 \mu \mathrm{M}$ dose of $\mathrm{ABA}$, the photosynthetic rate did not reach values close to zero (mean of $2,09 \mu \mathrm{molm}^{-2} \mathrm{~s}^{-1}$ ). After re-irrigation, the seedlings under water deficit recovered photosynthetic metabolism in 14 days ( $43^{\text {rd }}$ day), with values like those of the irrigated treatments.

The second suspension of irrigation occurred on the $69^{\text {th }}$ day after the start of the experiment. A subsequent application of the second dose of ABA occurred on the $94^{\text {th }}$ day. The seedlings from the treatments without irrigation (SI) reached photosynthetic rate values close to zero on day 36 after the second suspension of irrigation, which occurred on the $105^{\text {th }}$ day $\left(2^{\text {nd }} P 0\right)$. On the other hand, the seedlings from the SI $10 \mu \mathrm{M}$ treatment did not reach photosynthetic rate values close to zero but rather showed values lower than those of the irrigated seedlings. The seedlings were re-irrigated, and they then recovered photosynthetic metabolism in 22 days ( $127^{\text {th }}$ day), with values approaching those of the seedlings from the irrigated treatments.

For the irrigated seedlings with ABA application (I $10 \mu \mathrm{M}$ ), ABA did not increase the photosynthetic rates when compared to irrigation treatment (I) without ABA. These seedlings showed values with variations in the photosynthetic rate over several days. The data showed an increase, decrease, or no significant difference when compared to the irrigated treatments (I, without ABA) (Figure 1a).

In the first $1^{\text {st }} \mathrm{P} 0$, the seedlings reached photosynthetic rate values near zero on the $9^{\text {th }}$ day after the suspension of irrigation, whereas in the $2^{\text {nd }} \mathrm{PO}$, this was not achieved until the $36^{\text {th }}$ day. The difference in the number of days to reach the near-zero photosynthetic rate between the two cycles occurred due to climatic conditions. In the first cycle, the temperatures were high. In the second cycle, there was a drop in temperature and an increase in humidity due to large amounts of rainfall during this period (data not shown), which contributed to an increase in the relative humidity around the seedlings created a microclimate that may have favored the maintenance of the photosynthetic rate. 


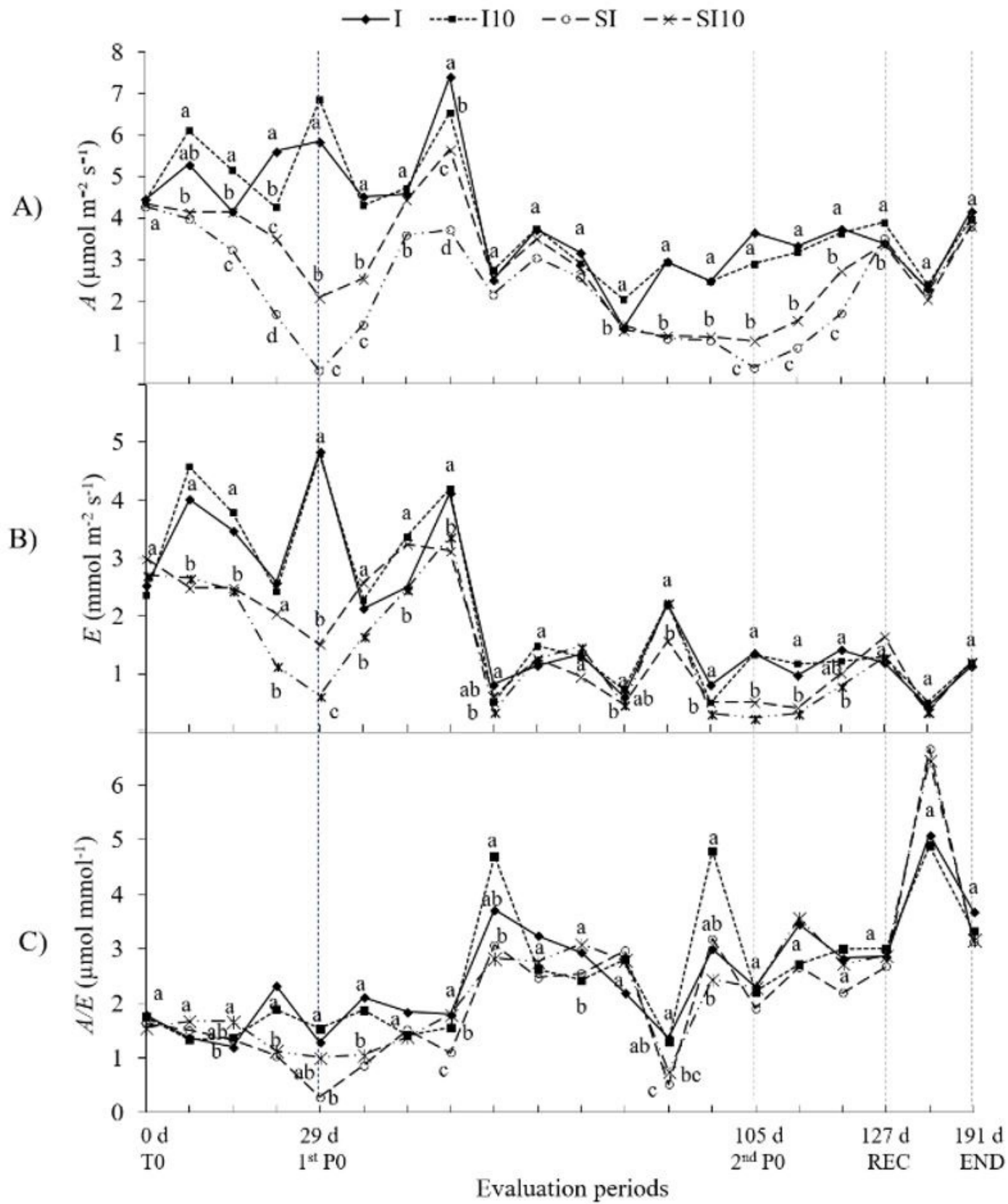

Figure 1. Photosynthetic rate $(A)$ - (A), transpiration rate $(E)$; (B) and water use efficiency $(A / E)$; $(C)$ as a function of the evaluation days of Ormosia arborea irrigated seedlings (I and I $10 \mu \mathrm{M}$ ABA) and submitted to water deficit conditions (SI and SI $10 \mu \mathrm{M}$ ABA). Continuous vertical line indicates the periods of evaluation: time zero (T0), first null photosynthesis ( $\left.1^{\text {st }} \mathrm{P} 0\right)$, second null photosynthesis ( ${ }^{2 \mathrm{nd}} \mathrm{P0}$ ), recovery (REC) and final evaluation (END).

The transpiration rate $(E)$ of the seedlings in irrigated treatments showed variation. However, treatment with ABA did not appear to affect transpiration in these treatments. That is, on most days, these treatments did not differ significantly from each other (Figure1b). After day 43, there was a marked reduction in transpiration due to the drop in temperature (data not shown).

The water deficit caused a reduction in transpiration for the seedlings grown under water stress, and the reductions were more pronounced when the photosynthetic rates were close to zero (Figure 1b). However, with ABA application (SI $10 \mu \mathrm{M}$ of $\mathrm{ABA}$ ), the seedlings did not show values near zero in the $1^{\text {st }} \mathrm{P} 0$. In the $2^{\text {nd }} \mathrm{P0}$, they did not vary significantly from the seedlings that were without ABA (SI), despite having superior values to the seedlings in that treatment. When the seedlings were rehydrated, their metabolism recovered, reaching levels close to the 
irrigated treatments and with no significant difference between all the treatments.

The seedlings from all treatments exhibited variations in their water use efficiency $(A / E)$ (Figure 1c). However, when the seedlings grown under water deficit restored their metabolism, they presented values close to those of the irrigated treatments, and there was no significant difference between them. Seedlings under water deficit treated with $10 \mu \mathrm{M}$ of $\mathrm{ABA}$ had values close to those of the irrigated treatments in the $1^{\text {stP0 }}$ ( $29^{\text {th }}$ day).

From the $8^{\text {th }}$ day on, the stomatal conductance $(g s)$ of the seedlings under water deficit was below that of the irrigated seedlings, with a sharp decline at the time of the $1^{\text {st }}$ and $2^{\text {nd }} \mathrm{P0}$ (Figure $1 \mathrm{a}$ ). The seedlings under water deficit and with $\mathrm{ABA}$ (SI $10 \mu \mathrm{M}$ ABA) were superior to the

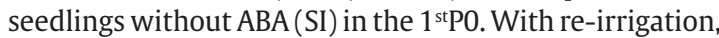
the seedlings under water deficit reestablished their gs values and reached the same level as the irrigated seedlings on the $51^{\text {st }}$ day (Figure $2 \mathrm{a}$ ), while the photosynthetic rate in these seedlings was reestablished on the $43^{\text {rd }}$ day (Figure 2a). There was a reduction in the gs values of the irrigated seedlings on the $43^{\text {rd }}$ day.

The values of the internal concentration of $\mathrm{CO}_{2}(\mathrm{Ci})$ fluctuated during the experiment, and the irrigated seedlings showed higher values than the other treatments on most days (Figure 2b). The seedlings under water deficit did not differ significantly from the irrigated seedlings when the photosynthetic rate reached null values in the $2^{\text {nd }}$ P0. When the seedlings were re-irrigated, the re-irrigated treatments reached values close to those of the irrigated seedlings, and they sometimes achieved even higher values.

In relation to carboxylation efficiency $(A / C i)$, the seedlings under water deficit presented lower values than the irrigated treatments (Figure $2 \mathrm{c}$ ); in the $1^{\text {st }}$ and $2^{\text {nd }} \mathrm{P0}$, the photosynthetic rates were close to zero.

The water potential $(\Psi \mathrm{w})$ of the leaves of 0 . arborea seedlings showed a significant interaction between the treatments and the periods of assessment. In the $1^{\text {st }} \mathrm{P}$, the seedlings subjected to water deficit had the lowest $\Psi \mathrm{W}$ values, differing significantly from the irrigated seedlings. The seedlings not treated with ABA and subjected to water deficit showed a significant reduction in $\Psi \mathrm{w}$, mainly in the $2^{\text {nd }} \mathrm{P0}$, with lower $\Psi \mathrm{W}$ values in the first and second cycles of photosynthesis near-zero (1.43MPa and 2.03 MPa, respectively) (Figure 3a).

In the $2^{\text {nd }} \mathrm{P} 0$, the reduction in water potential was even greater than in the $1^{\text {st }} \mathrm{F} 0$ for cultivation under water deficit and without $\mathrm{ABA}(\mathrm{SI})$. The irrigated seedlings without $\mathrm{ABA}$ (I) and with $\mathrm{ABA}(\mathrm{I} 10 \mu \mathrm{M} \mathrm{ABA})$ demonstrated no significant differences in $\Psi \mathrm{w}$ during the periods of photosynthesis close to zero ( $1^{\text {st }} \mathrm{P} 0$ and $\left.2^{\text {nd }} \mathrm{P} 0\right)$. In the recovery and END assessment, the seedlings from all treatment groups had $\Psi \mathrm{W}$ values close to zero, demonstrating that the water deficit treatments recovered, with no difference between the treatments.

The quantum efficiency of photosystem II (Fv/Fm) was reduced significantly in the seedlings under water deficit in the $1^{\text {st }}$ and $2^{\text {nd }} \mathrm{P} 0$, and the values did not recover after reirrigation. Thus, during the recovery and END phase, these seedlings still had lower efficiency values when compared to the other treatments (Figure 3b). It is emphasized that the seedlings under water deficit that received ABA began to recover, and at the end of the assessment period, they showed values above the stressed seedlings without ABA. However, both groups had values less than 0.75 .

Concerning antioxidant enzymes, the activity of catalase (CAT) on leaves showed higher values in the plants cultivated under water deficit in the two cycles of photosynthesis close to zero, when compared with the irrigated seedlings. However, in the $1^{\text {st }} \mathrm{P} 0$, the irrigated seedlings treated with $10 \mu \mathrm{M}$ ABA (I 10) did not differ significantly from seedlings under water deficit without ABA (Figure 4a). Regarding the irrigated seedlings treated with $\mathrm{ABA}(\mathrm{I} 10 \mu \mathrm{M} \mathrm{ABA})$, the values were higher than those of the irrigated treatment without ABA (I) in the two cycles of photosynthesis close to zero. This was especially apparent in the $2^{\text {nd }} \mathrm{P} 0$, where there was a significant difference between the treatments.

During the period of recovery (REC) and the END period, the treatments under water deficit without ABA (SI) presented higher values than the other treatments. In the roots, there were higher values of CAT in the treatments under water deficit in the $1^{\text {st }} \mathrm{P} 0$, the $2^{\text {nd }} \mathrm{P} 0$, and REC, and the application of ABA kept the CAT activity at a high level at the end of the assessments (Figure $5 B$ ). Both in the leaves and roots, the application of $A B A$ to seedlings under water deficit did not result in a significant difference when compared to the treatment without ABA(SI) during photosynthesis periods close to zero.

Peroxidase activity (POD) was higher in the leaves of seedlings grown under water deficit without $A B A(S I)$ in the $1^{\text {st }}$ and $2^{\text {nd }}$ P0 (Figure $6 \mathrm{~A}$ ). Regarding the roots, the seedlings under water deficit had values higher than those that were irrigated in the second period of photosynthesis close to zero ( $2^{\text {nd }} \mathrm{P} 0$ ). Additionally, there was no difference between the treatments with each form of irrigation in the $1^{\text {st }}$ and $2^{\text {nd }} \mathrm{P} 0$. The seedlings under water deficit showed higher POD activity than the irrigated seedlings, especially when they received ABA (SI 10) until the REC and END periods (Figure $5 \mathrm{~b}$ ).

Superoxide dismutase (SOD) activity on the leaves of seedlings under water deficit without ABA(SI) was superior to other treatments in the $1^{\text {st }}$ and $2^{\text {nd }} P 0$. The seedlings under water deficit that received ABA did not show significant increase in SOD during these periods. The irrigated and non-irrigated treatments with ABA showed variation in values (Figure 6a). For the roots, SOD was reduced in all treatments, but the seedlings that had gone through water stress showed significant increases during REC and END (Figure 6b).

\section{Discussion}

Ormosia arborea seedlings subjected to water deficit showed a reduction in photosynthetic metabolism and leaf water potential, also presented an increased activity of antioxidant enzymes. However, with the application of $A B A$, responses were less pronounced, suggesting that the ABA mitigated the stressful effects of water deficit.

Although there was no significant variation between the water restriction treatments in the $1^{\text {st }} \mathrm{P} 0$, in the $2^{\text {nd }}$ 


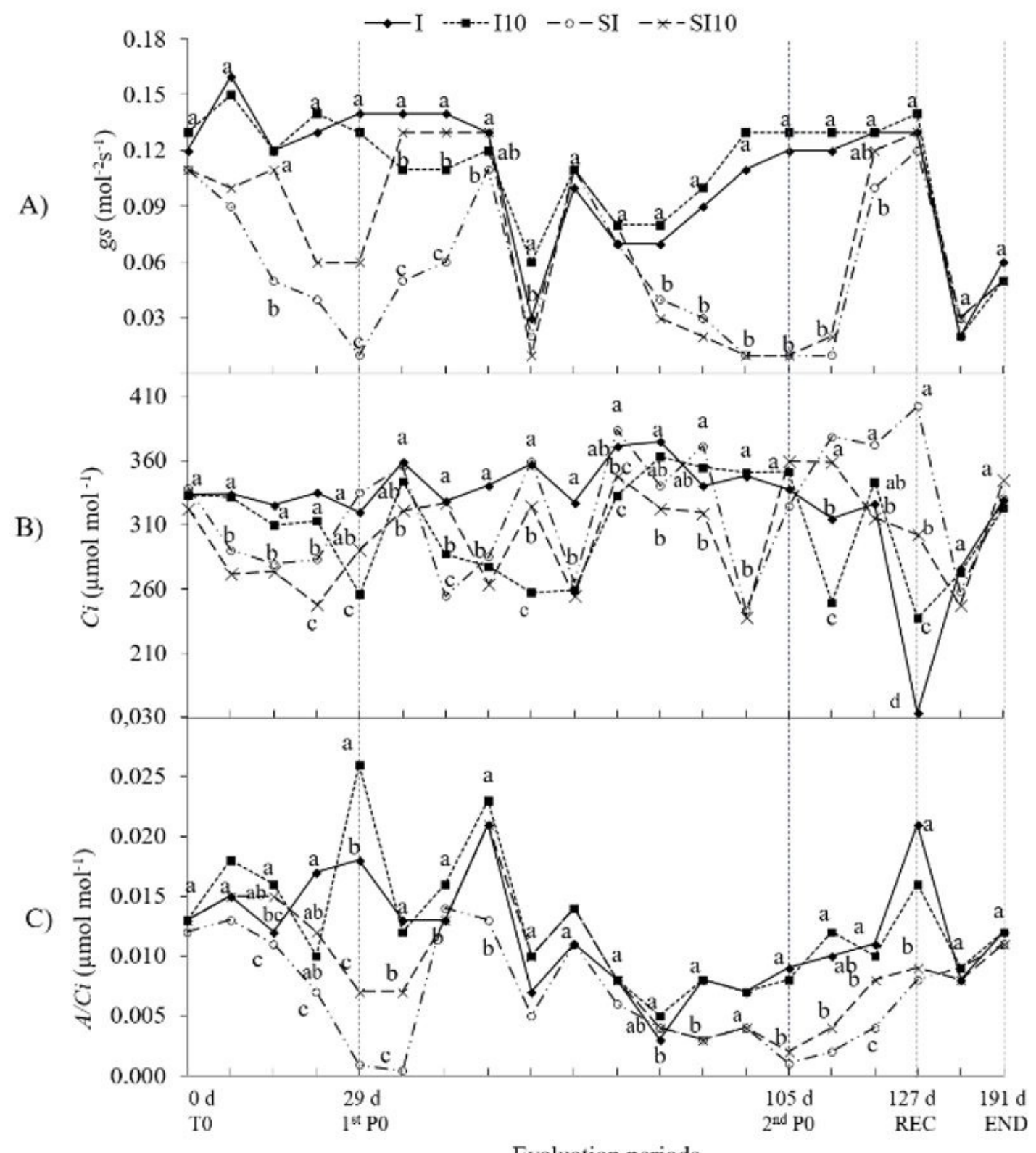

Evaluation periods

Figure 2. Stomatal conductance ( $\mathrm{gs}$ ) - (A) internal $\mathrm{CO}_{2}$ concentration ( $\mathrm{Ci}$ ); (B) and instantaneous carboxylation efficiency $\mathrm{CO}_{2}(\mathrm{~A} / \mathrm{Ci})$; (C) of Ormosia arborea irrigated seedlings (I and I $10 \mu \mathrm{M}$ ABA) and submitted to water deficit conditions (SI and SI $10 \mu \mathrm{M}$ ABA). Continuous vertical line indicates the periods of evaluation: time zero (T0), first null photosynthesis ( $\left.1^{\text {st }} \mathrm{P} 0\right)$, second null photosynthesis ( $2^{\text {nd }} \mathrm{P} 0$ ), recovery (REC) and final evaluation (END).

P0, the seedlings under water deficit that were treated with $10 \mu \mathrm{M}$ ABA (I $10 \mu \mathrm{M}$ ABA), showed greater $\Psi \mathrm{w}$ when compared to seedlings without $A B A$. The exogenous application of ABA in plants can increase their tolerance to stress by promoting the closure of stomata during times of water deficit, thus maintaining turgescence by reducing transpiration (Pacheco et al., 2011; Pantin et al., 2012). We believe that this mechanism may have contributed to the maintenance of turgescence in the leaves of 0 . arborea, helped to avoid damage and favored the recovery of $\Psi \mathrm{w}$ in seedlings after re-irrigation according to observations at the end of the assessments. However, irrigated 0. arborea seedlings with or without ABA did not present significant differences, suggesting that $A B A$ did not influence the water potential ( $\Psi \mathrm{w})$ of these seedlings.

It was observed that ABA did not promote the maintenance of $g s$ of the seedlings, which showed variation in the values. The Calendula officinalis $\mathrm{L}$. seedlings that 


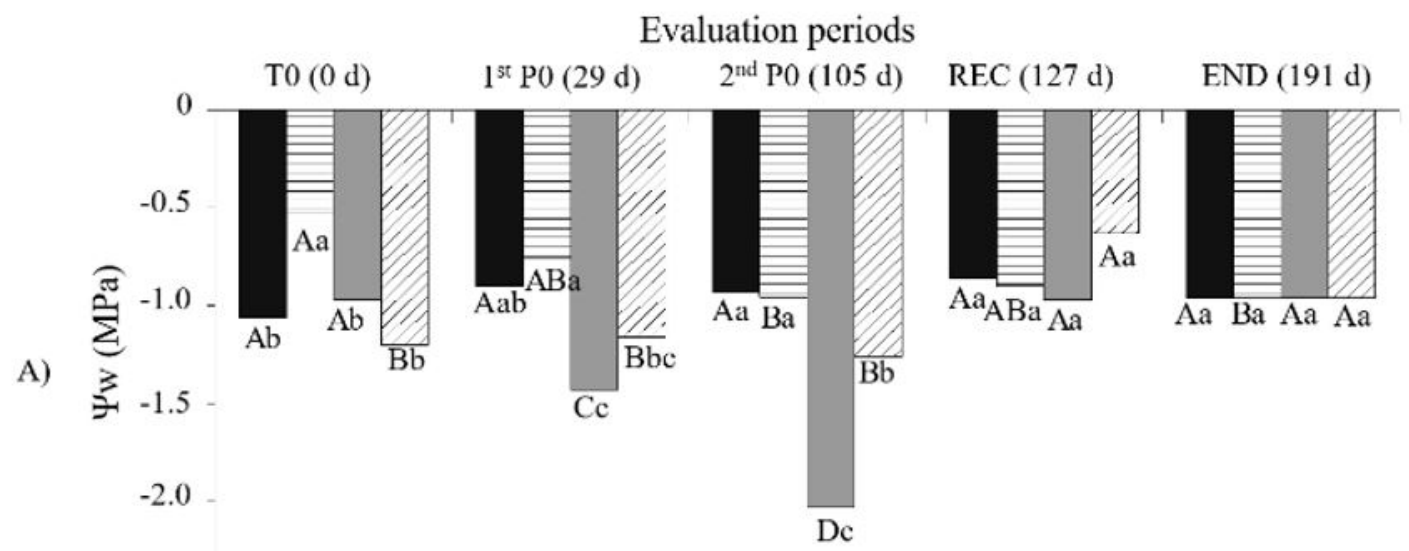

$-2.5-$

- $\mathrm{I} \boxminus \mathrm{I} 10 \square \mathrm{SI} \unlhd \mathrm{SI} 10$

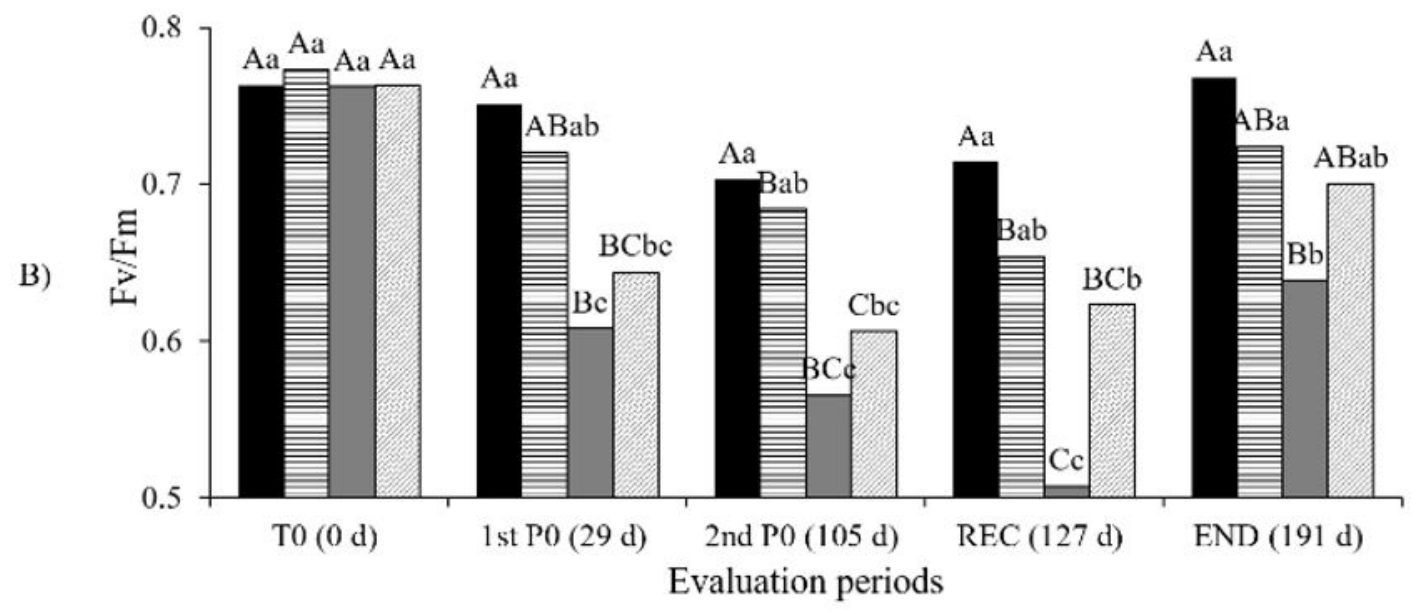

Figure 3. Water potential ( $\Psi$ w) (A) and Potential efficiency quantum of photosystem II (Fv/Fm) (B) as a function of the evaluation periods between irrigated seedlings (I) of Ormosia arborea (I and I $10 \mu \mathrm{M} \mathrm{ABA}$ ) and submitted to the water deficit condition (SI and SI $10 \mu \mathrm{M} \mathrm{ABA}$ ). Lowercase letters compare the different treatments in the same evaluation period and uppercase letters compare the same treatment in the different evaluation periods.

were irrigated and treated with 10 and $100 \mu \mathrm{M}$ of $\mathrm{ABA}$ did not show significant differences in gs from those that did not receive ABA (Pacheco et al., 2011). Even with abundant water, the exogenous application of ABA did not increase $g s$ in the seedlings of $O$. arborea, Pterogyne nitens Tul. and Aspidosperma polyneuron Mull. Arg which is also observed in the results of the irrigated treatments that presented a decrease in stomatal conductance when subjected to low water availability in the soil (Tonello and Teixeira Filho, 2012).

The application of 10 and $100 \mu \mathrm{M}$ doses of $\mathrm{ABA}$ in C. officinalis under water deficit did not promote prolonged protective effects or attenuation of the effects of the water deficiency on gas exchange. It has been observed that in stressed $C$. officinalis seedlings at the dose of $10 \mu \mathrm{M}$ ABA, the photosynthetic rate was slightly higher than for the other treatments under water deficiency (Pacheco et al., 2011). This like O. arborea, although there was no significant variation in treatments under water deficiency. These results suggest that the lower dose is efficient in promoting protective responses.

There was a significant increase in $\mathrm{Ci}$ in the plants under water deficit starting on the $8^{\text {th }}$ day after irrigation was suspended, as compared to the plants in the irrigated treatment. On the last day of water deficit, there was an average of $15 \%\left(1^{\text {st }} \mathrm{P0}\right)$ to $25 \%\left(2^{\text {nd }} \mathrm{P0}\right)$ increase in $\mathrm{C}$, independent of the application of $\mathrm{ABA}$, possibly resulting from the reduction in the degree of stomatal opening, causing a decrease in the photosynthetic rate. However, on the $139^{\text {th }}$ day, at the end of the experiment, the seedlings under water deficit presented lower of $\mathrm{Ci}$, demonstrating that these seedlings had reestablished themselves. In the 


\section{目 $\square \mathrm{Il} 0 \square \mathrm{SI} \square \mathrm{SI} 10$}

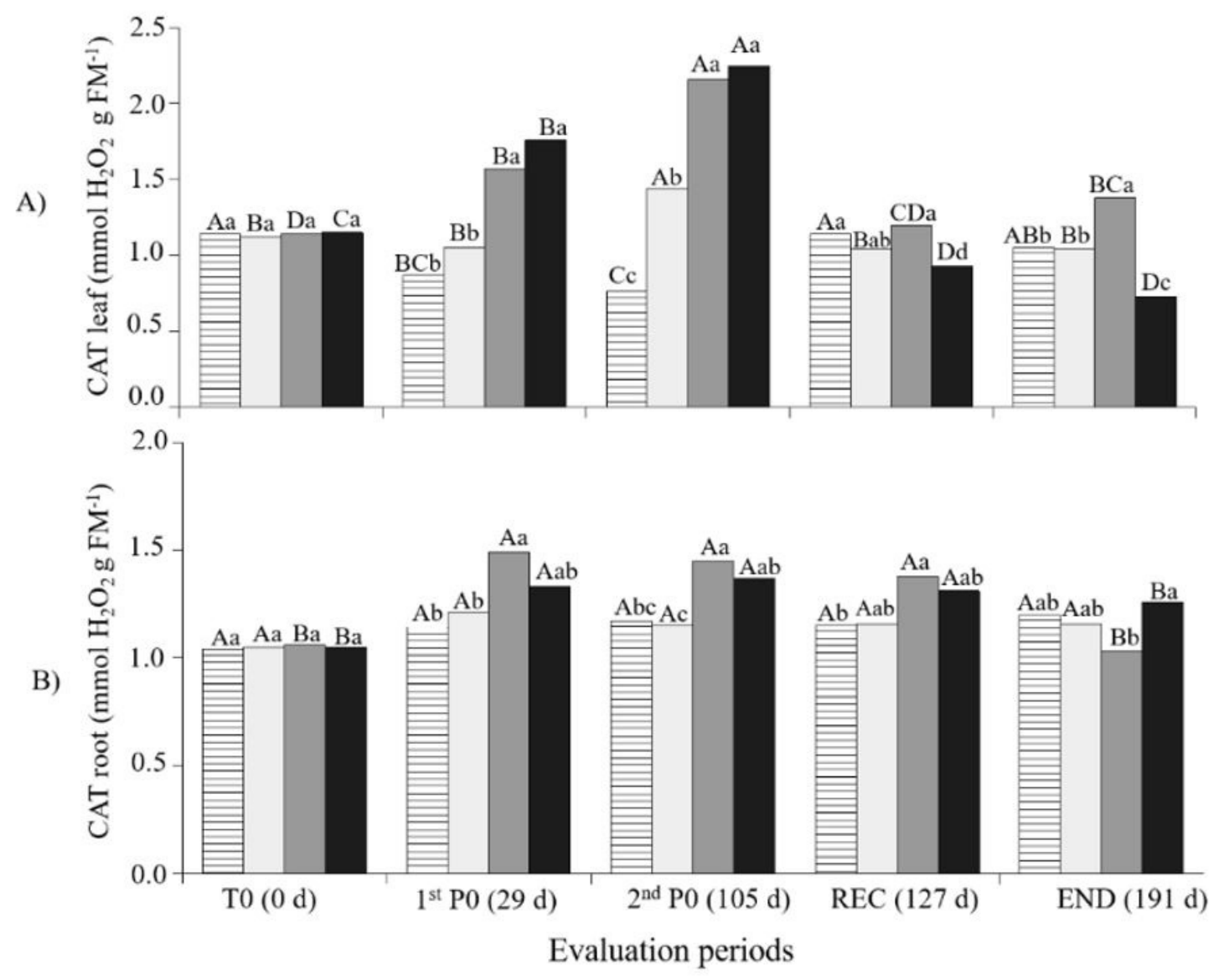

Figure 4. Activity of the catalase enzyme in leaf (A) and root (B) of Ormosia arborea seedlings irrigated (I and I $10 \mu \mathrm{M} A B A)$ and submitted to water deficit conditions ( $\mathrm{SI}$ and SI $10 \mu \mathrm{M} \mathrm{ABA}$ ) in the different evaluation periods: zero time (T0), first null photosynthesis ( $1^{\text {st }} \mathrm{P0}$ ), second null photosynthesis ( $2^{\text {nd }} \mathrm{P} 0$ ), recovery (REC) and final evaluation (END). Upper case letters differ between trial times and lowercase letters between treatments.

END assessment (END), they presented values like the irrigated seedlings. This result was also apparent for C. officinalis seedlings under water stress with or without ABA, which presented higher values at the end of the assessments (Pacheco et al., 2011).

About stressed 0 . arborea seedlings that received ABA, although they had reduction in stomatal conductance, the photosynthetic rate did not reach values close to zero in the two cycles of null photosynthesis. Thus, suggesting that ABA promoted higher adjusted to water deficit for these seedlings.

It should be emphasized that, in the $2^{\text {nd }} \mathrm{P} 0$, the reduction in transpiration for seedlings in all treatments, including the irrigated treatments, may have been due to the drop in temperature, including foliar temperature (data do not show). It bears mentioning that the transpiration levels of seedlings under water deficit were restored after irrigation, thus achieving levels that did not differ from irrigated treatments. We observed that the photosynthetic rate decreased when the temperature decreased ( $43^{\text {rd }}$ day data do not show), even in the irrigated plants. When there is a decrease in temperature, stomatal closure occurs, consequently, there are reductions in $\mathrm{CO}_{2}$ entrance, stomatal conductance, photosynthetic rate, and transpiration. Thus, water supply alone does not promote the optimization of gas exchange; temperature and humidity also influence these processes (Taiz et al., 2017).

In this study, we have verified that decreases in the photosynthetic rate observed under water deficit can largely be explained by stomatal closure. It is important to note, however, that reductions in photosynthesis rates were accompanied by an increase in the internal $\mathrm{CO}_{2}$ concentration and a reduction in the instantaneous carboxylation efficiency of Rubisco. This is evidence of the existence of non-stomatal limitations, as suggested about another species by Campelo et al. (2015).

We believe that the progressive decrease in gs, nearly reaching zero under water deficit, can be considered a strategy to reduce the rate of transpiration and keep foliar tissues hydrated. This was also observed for M. urundeuva 

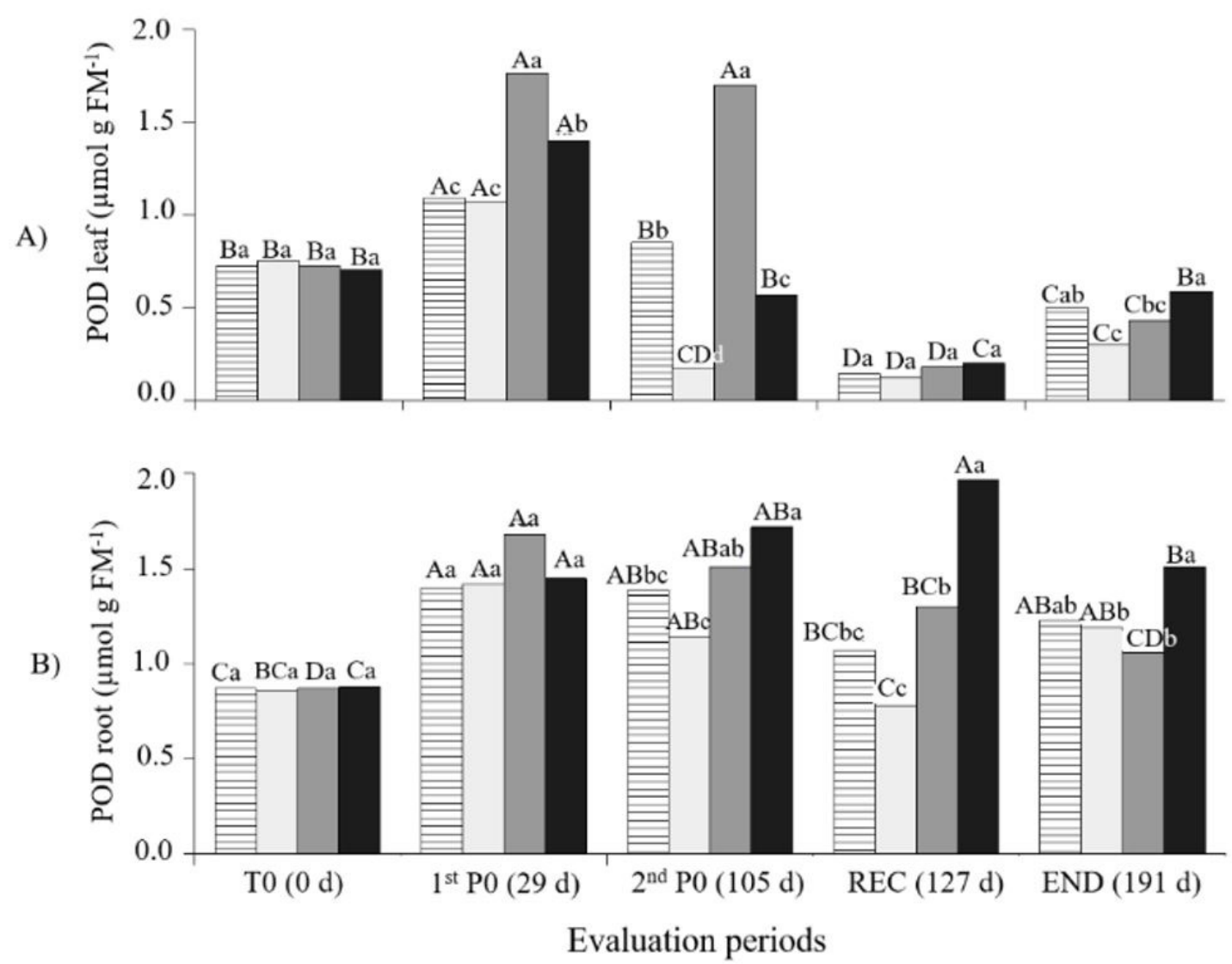

Figure 5. Enzymatic activity of peroxidase in leaves (POD Leaves) (A) and roots (POD Roots) (B) of Ormosia arborea seedlings irrigated (I and I $10 \mu \mathrm{M} \mathrm{ABA}$ ) and submitted to water deficit conditions (SI and SI $10 \mu \mathrm{M} \mathrm{ABA)} \mathrm{in} \mathrm{the} \mathrm{different} \mathrm{evaluation} \mathrm{periods:} \mathrm{zero} \mathrm{time} \mathrm{(T0),}$ first null photosynthesis $\left(1^{\text {st }} \mathrm{P} 0\right)$, second null photosynthesis $\left(2^{\text {nd }} \mathrm{P} 0\right)$, recovery $(\mathrm{REC})$ and final evaluation (END). Upper case letters differ between trial times and lowercase letters between treatments.

(Costa et al., 2015). The authors observed in their review that values of gs between $0.05-0.1 \mathrm{molm}^{-2} \mathrm{~s}^{-1}$ suggest that plants are under moderate water deficit and that photosynthesis is limited by the stomata, reducing the influx of $\mathrm{CO}_{2}$. Thus, we suggest that gs values lower than $0.05 \mathrm{molm}^{-2} \mathrm{~s}^{-1}$, as observed in this study for 0 . arborea seedlings, are indicative of severe water deficit and are accompanied by non-stomatal limitations. Among these limitations are damages to the photochemical apparatus through the disintegration of thylakoid membranes. This may cause a decrease in the Photosystem II electron transport rate, reducing ATP synthesis, as well as decreasing the activity and regeneration capacity of Rubisco.

There was a significant increase in $\mathrm{C} i$ in the plants under water deficit starting on the 8th day after irrigation was suspended, as compared to the plants in the irrigated treatment. On the last day of water deficit, there was an average of $15 \%\left(1^{\text {st }} \mathrm{P} 0\right)$ to $25 \%\left(2^{\text {nd }} \mathrm{P} 0\right.$ ) increase in IC, independent of the application of $\mathrm{ABA}$, possibly resulting from the reduction in the degree of stomatal opening, causing a decrease in the photosynthetic rate. Seedlings under water deficit presented lower of $\mathrm{Ci}$, demonstrating that these seedlings had reestablished themselves. In the END assessment (END), they presented values like the irrigated seedlings. This result was also apparent for C. officinalis seedlings under water stress with or without $A B A$, which resented higher values at the end of the assessments (Pacheco et al., 2011).

We observe that at the end of the assessments, the $\mathrm{A} / \mathrm{C} i$ ratio decreased, even for the irrigated seedlings, what we assign to the decrease is the ambient and foliar temperature during the period. Another fact which we highlight, based on reports by Costa et al. (2015), Bertolli et al. (2015) and Campelo et al. (2015), is that in conditions of water deficit, there is a decrease in $\mathrm{CO}_{2}$ assimilation and the quantum yield of Photosystem II. The afore mentioned authors observed that there are no stomatal factors related to the reduction of $\mathrm{CO}_{2}$ assimilation, such as damage to the Photosystem II reaction center, which can be reversed after hydration.

The quantum efficiency of the photosystem (Fv/Fm) decreased in stressed plants and did not recover at the end of the assessments, except for those who received 


\section{目I $\square \mathrm{I} 10 \square \mathrm{SI} \square \mathrm{SI} 10$}

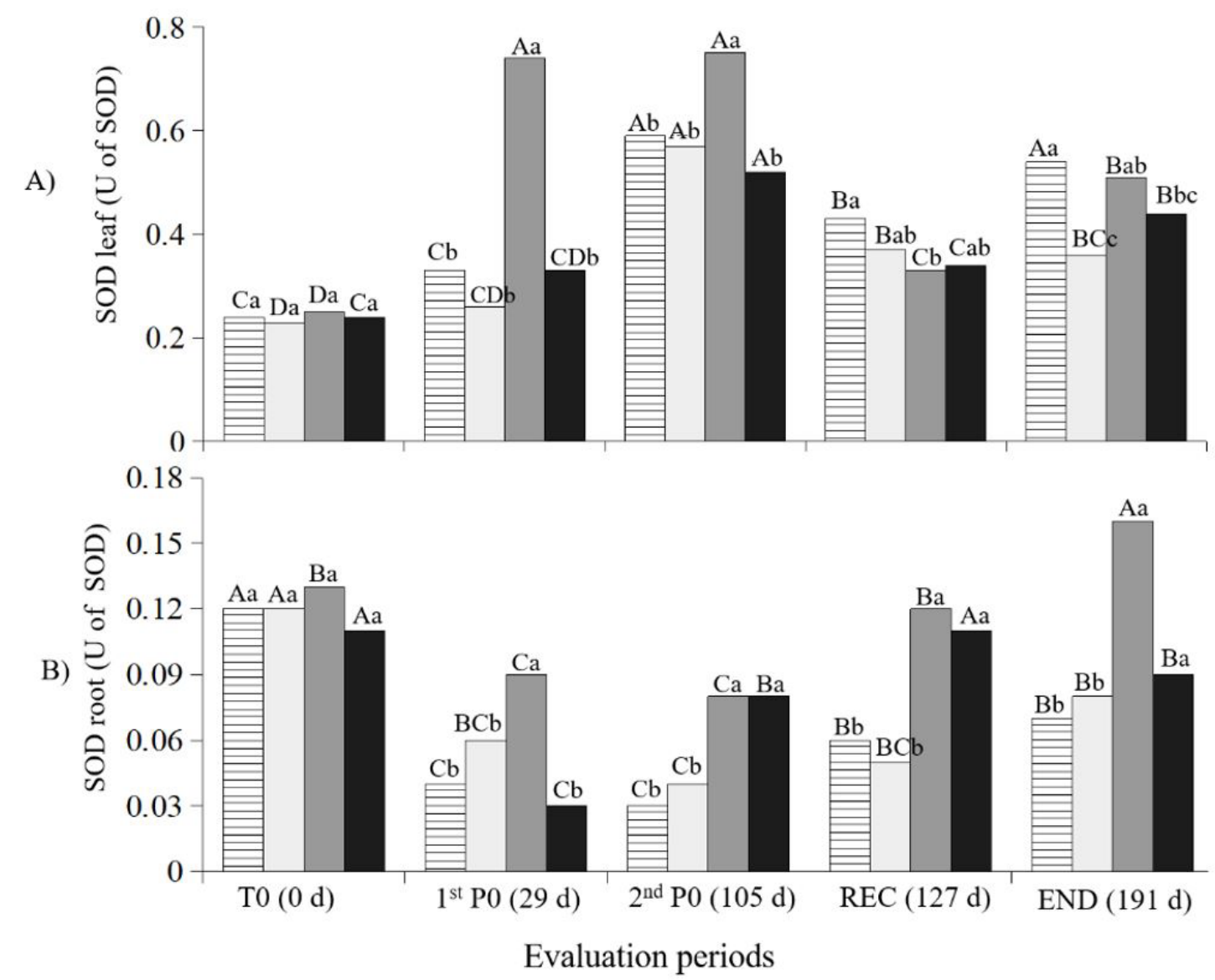

Figure 6. Enzymatic activity of superoxide dismutase in leaves (SOD Leaves) (A) and roots (SOD roots) (B) of Ormosia arborea seedlings irrigated (I and I $10 \mu \mathrm{M} \mathrm{ABA}$ ) and submitted to water deficit conditions (SI and SI $10 \mu \mathrm{M} \mathrm{ABA}$ ) in the different evaluation periods: zero time (T0), first null photosynthesis $\left(1^{\text {st }} \mathrm{P} 0\right)$, second null photosynthesis $\left(2^{\text {nd }} \mathrm{P} 0\right)$, recovery $(\mathrm{REC})$ and final evaluation (END). Upper case letters differ between trial times and lowercase letters between treatments.

ABA. The decrease in efficiency to values below 0.75 in all plants, starting with the $1^{\text {st }} \mathrm{P} 0$, can be attributed to the high temperature during the $1^{\text {st }} \mathrm{P} 0$. Although the temperature decreased after that period, there continued to be variation and high-temperature spikes. For this reason, we believe that the plants did not have time to recover, even for those plants that received ABA.

The literature report changes in Fv/Fm in plants subjected to water stress with species of different ecological distribution. Campelo et al. (2015) evaluated six forest species (Astronium fraxinifolium Schott, Calophyllum brasiliense Cambess, Handroanthus serratifolius Vahl, Handroanthus impetiginosa Mart, Simarouba amara Aubl, and S. macrophylla King) as a function of suppression of water supply in the soil. They observed that the species $S$. macrophylla, C. brasiliense, and H. serratifolius were more sensitive to water suppression compared to the other species, since they exhibited decreased photochemical efficiency of photosystem II, as well as a decrease in photosynthesis. These species feature ecological distribution like that of 0 . arborea, mainly C. brasiliense, suggesting that even tolerating the hydric deficit, the photochemistry of photosynthesis suffers change.

In a study involving the tree species of the Caatinga (a desert xeric scrubland and thorn forest ecoregion) during the dry and rainy seasons (Trovão et al., 2007), found that, of eleven species studied, seven did not experience changes in Fv/Fm during the periods of study. The other four had minimal reductions that were attributed to the evolutionary characteristics of these species.

For plants with an intact photosynthetic apparatus, the Fv/Fm ratio should range between 0.75 and 0.85 (BolharNordenkampf et al., 1989). A decrease in this ratio with water deficit indicates the presence of photoinhibition damage to the PSII reaction center (Björkman and Demmig, 1987; Lage-Pinto et al., 2012). Beginning with the $1^{\text {st }} \mathrm{P0}$, the values remained below 0.75 , suggesting that even 
after re-irrigation, the 0 . arborea seedlings were not able to reestablish the Fv/Fm ratio.

The 0 . arborea seedlings subjected to water stress showed an increase in antioxidant enzymes (except for SOD) regardless of the presence of ABA during periods of suspended irrigation ( $1^{\text {st }} \mathrm{P} 0$ and $2^{\text {nd }} \mathrm{P} 0$ ). This is probably in response to the production of reactive oxygen species (ROS), which usually are produced under these conditions, although they have not been quantified in this work. Note that the irrigated seedlings also had elevated enzyme levels. We attribute this result to the elevated temperature observed in the T0 and $1^{\text {st }}$ P0 periods, as suggested by Ribeiro et al. (2012) in relation to other plants. This condition certainly accentuated the water deficit.

During periods when photosynthesis was close to zero, ABA likely promoted adjust in seedlings during exposure to water deficit, stimulated antioxidant enzyme activity. Understanding the antioxidant system of plants is essential for the selection of approaches that results in less sensitivity to water deficit and increased tolerance to drought (Moraes et al., 2015).

Considering that this specie also present potential to survive in temporarily flooded areas (Junglos et al., 2018), we justify its occurrence in several biomes as Atlantic forest and Cerrado in the Gallery forests and urban forestry.

\section{Conclusion}

ABA minimizes the reduction in the photosynthetic metabolism and water potential of the leaf, however, it does not increase the antioxidant activity of the 0 . arborea seedlings under water deficit. These results suggest that this species exhibits plasticity, which enables it to survive also in environments subject to temporary water deficit regardless of the supplementation of $A B A$. We suggest that other doses of $A B A$ be researched to expand the beneficial effect of ABA on this species.

\section{Acknowledgements}

The authors are grateful for the financial suportby FUNDECT-MS (Fundação de Apoio ao Desenvolvimento do Ensino, Ciência e Tecnologia do Estado de Mato Grosso do Sul), CAPES (Coordenação de Aperfeiçoamento de Pessoal de Nível Superior) and CNPq (Conselho Nacional de Desenvolvimento Científico e Tecnológico).

\section{References}

BERTOLLI, S.C., SOUZA, J. and SOUZA, G.M., 2015. Caracterização fotossintética da espécie isohídrica pata-de-elefante em condições de deficiência hídrica. Revista Caatinga, vol. 28 , no. 3, pp. 196-205. http://dx.doi.org/10.1590/198321252015v28n322rc.

BJÖRKMAN, O. and DEMMIG, B., 1987. Photon yield of $\mathrm{O}_{2}$ evolution and chlorophyll fluorescence characteristics at 77 K among vascular plants of diverse origins. Planta, vol. 170 , no. 4, pp. 489-504. http://dx.doi.org/10.1007/BF00402983. PMid:24233012.
BOLHAR-NORDENKAMPF, H.R., LONG, S.P., BAKER, N.R., OQUIST, G., SCHREIBER, U. and LECHNER, E.G., 1989. Chlorophyll fluorescence as probe of the photosynthetic competence of leaves in the field: a review of current instrumentation. Functional Ecology, vol. 3, no. 4, pp. 497-514. http://dx.doi. org/10.2307/2389624.

BROETTO, F., 2014. Métodos de trabalho em bioquímica vegetal e tecnologia de enzimas. São Paulo: UNESP, 92 p.

CAMPELO, D.H., LACERDA, C.F., SOUSA, J.A., CORREIA, D., BEZERRA, A.M.E., ARAÚJO, J.D.M. and NEVES, A.L.R., 2015. Trocas gasosas e eficiência do fotossistema ii em plantas adultas de seis espécies florestais em função do suprimento de água no solo. Revista Árvore, vol. 39, no. 5, pp. 973-983. http://dx.doi. org/10.1590/0100-67622015000500020.

CARNEIRO, M.M.L.C., DEUNER, S., OLIVEIRA, P.V., TEIXEIRA, S.B., SOUSA, C.P., BACARIN, M.A. and MORAES, D.M., 2011. Atividade antioxidante e viabilidade de sementes de girassol após estresse hídrico e salino. Revista Brasileira de Sementes, vol. 33, no. 4, pp. 752-761. http://dx.doi.org/10.1590/S0101-31222011000400017.

CARVALHO, P.E.R., 2004 [viewed 3 April 2019]. Coronheira (Ormosia arborea) [online]. Agência Embrapa de Informação Tecnológica. Available from: http://www.agencia.cnptia.embrapa.br/ Agencia16/AG01/arvore/AG01_23_911200585232.html

COSTA, A.S., FREIRE, A.L.O., BAKKE, I.A. and PEREIRA, F.H.F., 2015. Respostas fisiológicas e bioquímicas de plantas de aroeira (Myracrodruon urundeuva Allemão) ao déficit hídrico e posterior recuperação. Irriga, vol. 20, no. 4, pp. 705-717. http://dx.doi. org/10.15809/irriga.2015v20n4p705.

FERREIRA, D.F., 2011. Sisvar: a computer statistical analysis system. Ciência e Agrotecnologia, vol. 35, no. 6, pp. 1039-1042. http:// dx.doi.org/10.1590/S1413-70542011000600001.

GOULART, M.F., LOVATO, M.B., DE VASCONCELLOS BARROS, F., VALLADARES, F. and LEMOS-FILHO, J.P., 2011. Which extent is plasticity to light involved in the ecotypic differentiation of a tree species from savana and forest? Biotropica, vol. 43, no. 6, pp. 695-703. http://dx.doi.org/10.1111/j.1744-7429.2011.00760.x.

JUNGLOS, F.S., JUNGLOS, M.S., DRESCH, D.M., BENTO, L.F., SANTIAGO, E.F., MUSSURY, R.M. and SCALON, S.P.Q., 2018. Morphophysiological responses of Ormosia arborea (Vell.) Harms (Fabaceae) seedlings under flooding and post-flooding conditions. Australian Journal of Botany, vol. 66, no. 7, pp. 489499. http://dx.doi.org/10.1071/BT17206.

LAGE-PINTO, F., BERNINI, E., OLIVEIRA, J.G. and VITÓRIA, A.P., 2012. Photosynthetic analyses of two native Atlantic Forest species in regenerative understory of eucalyptus plantation. Brazilian Journal of Plant Physiology, vol. 24, no. 4, pp. 95-106. http:// dx.doi.org/10.1590/S1677-04202012000200003.

LORENZI, H., 2008. Árvores Brasileiras: manual de identificação e cultivo de plantas arbóreas nativas do Brasil. 5. ed. Nova Odessa, SP: Instituto Plantarum, Vol. 1, pp. 384.

MORAES, P.F., DE LAAT, D.M., SANTOS, M.E.A.H.P., COLOMBO, C.A. and KIIHL, T., 2015. Expressão gênica diferencial em genótipos de mamona (Ricinus communis L.) submetidos a déficit hídrico induzido por PEG. Bragantia, vol. 74, no. 1, pp. 25-32. http:// dx.doi.org/10.1590/1678-4499.0207.

OKASABE, Y., OKASABE, K., SHINOZAKI, K. and TRAN, L.-S.P., 2014. Response of plants to water stress. Frontiers of Plant Science, vol. 5, pp. 1-8. http://dx.doi.org/10.3389/fpls.2014.00086.

PACHECO, A.C., CAMARGO, P.P., CASTRO, A. and SOUZA, G.M., 2011. Water deficit and ABA application on leaf gas exchange and flavonoid content in marigold (Calendula officinalis L.). Acta Scientiarum. Agronomy, vol. 33, no. 2, pp. 275-281. http://dx.doi. org/10.4025/actasciagron.v33i2.6390. 
PANTIN, F., MONNET, F., JANNAUD, D., COSTA, J.M., RENAUD, J., MULLER, B., SIMONNEAU, T. and GENTY, B., 2012. The dual effect of abscisic acid on stomata. The New Phytologist, vol. 197, no. 1, pp. 65-72. http://dx.doi.org/10.1111/nph.12013. PMid:23106390.

RESENDE, C.F., PACHECO, V.S., DORNELLAS, F.F., OLIVEIRA, A.M.S. FREITAS, J.C. and PEIXOTO, P.H.P., 2019. Responses of antioxidant enzymes, photosynthetic pigments and carbohydrates in micropropagated Pitcairnia encholirioides L.B. Sm. (Bromeliaceae) under ex vitro water deficit and after rehydration. Brazilian Journal of Biology $=$ Revista Brasileira de Biologia, vol. 79, no. 1, pp. 53-62. http://dx.doi.org/10.1590/1519-6984.175284. PMid:29590251.

RIBEIRO, G., PIMENTEL, A.J.B., SOUZA, M.A., ROCHA, J.R.A.S. and FONSECA, W.B., 2012. Stress for high temperatures in wheat: impact on development and mechanisms of tolerance. Revista Brasileira de Agrociencia, vol. 18, pp. 133-142.

RODRIGUES, P.M.S.A., SILVA, J.O.B., EISENLOHR, P.V. and SCHAEFER, C.E., 2015. Climate change effects on the geographic distribution of specialist tree species of the Brazilian tropical dry forests. Brazilian
Journal of Biology = Revista Brasileira de Biologia, vol. 75, no. 3, pp. 679684. http://dx.doi.org/10.1590/1519-6984.20913. PMid:26465729.

SHINOZAKI, K. and YAMAGUCHI-SHINOZAKI, K., 1997. Gene expression and signal transduction in water-stress response. Plant Physiology, vol. 115, no. 2, pp. 327-334. http://dx.doi. org/10.1104/pp.115.2.327. PMid:12223810.

SOUZA, C.C., OLIVEIRA, F.A., SILVA, I.F. and AMORIM NETO, M.S., 2000. Avaliação de métodos de determinação de água disponível e manejo da irrigação em terra roxa sob cultivo de algodoeiro herbáceo. Revista Brasileira de Engenharia Agrícola e Ambiental, vol. 4, no. 3, pp. 338-342. http://dx.doi.org/10.1590/S1415-43662000000300006.

TAIZ, L., ZEIGER, E., MØLLER, I.M. and MURPHY, A., 2017. Fisiologia e desenvolvimento vegetal. 6. ed. Porto Alegre: Artmed, 858 p.

TONELLO, K.C. and TEIXEIRA FILHO, J., 2012. Ecophysiology of three native species from a Brazilian atlantic forest with different water regimes. Irriga, vol. 17, pp. 58-101.

TROVÃO, D.M.B.M., FERNANDES, P.D., ANDRADE, L.A. and DANTASNETO, J.D., 2007. Seazonal variations of physiological aspects of Caatinga species. Revista Brasileira de Engenharia Agrícola e Ambiental, vol. 11, no. 3,pp.307-311.http://dx.doi.org/10.1590/S1415-43662007000300010. 